\title{
Football Activism as Political Contention: Contextual Determinants of Membership in the Association of Supporters of Hajduk Split Josip Glaurdić \\ Université du Luxembourg
}

Where do politically activist football supporters come from? What are the social conditions under which they are successfully recruited and mobilised? This article answers those questions by analysing a unique dataset of more than 43 thousand members of Our Hajduk - the association of supporters of the Croatian club Hajduk Split - as well as a host of data on the communities they live in. The analysis shows that Our Hajduk thrives exactly in the same areas where most other social, civil, and political organisations thrive: among the more educated and more socioeconomically successful. Most importantly, the analysis shows that the pattern of Our Hajduk membership closely follows the patterns of political affiliation and participation in Croatia's electoral arena and is guided by the opposition to political players who have dominated Croatian football and turned it into a social field marked by corruption and mismanagement.

On a warm November day in 2014 , more than thirty thousand people assembled to protest on the seaside promenade in Croatia's second largest city of Split. The proximate cause of their protest were the events of the previous week when the supporters of the local football club Hajduk Split were not allowed to enter the Maksimir stadium in the country's capital of Zagreb prior to Hajduk's match with their arch-rivals Dinamo Zagreb. Hajduk's players refused to play the game without their supporters and the match was summarily registered as a 3-0 win for Dinamo, which prompted outrage not only among hardcore Hajduk supporters. This episode, however, was just the final straw in a complex relationship involving Hajduk, Dinamo, the Croatian Football Federation (HNS), and the national authorities, which had been building up in acrimony and conflict since Croatia's independence in 1991. The motivation of the assembled demonstrators a diverse mix of ultras and families of all generations - was perfectly captured by an ardent supporter of Hajduk Benjamin Perasović who addressed them that afternoon from a makeshift stage: "What we have here is the beginning of a social movement against injustice, mafia, and corruption... We are calling for the depersonalisation, depoliticisation, decriminalisation, and democratisation of Croatian football!" (Alač, 2014)

The protest changed little in Croatian football which is to this day marked by corruption, match fixing, financial mismanagement, and political connections. Nevertheless, Perasović was correct. 
The protest did serve as one of the foundations of a social movement of Hajduk supporters for a clean and fair club, league, football federation, and politics in general. Within a year, supporters took over association membership operations from club management and the membership figures skyrocketed from about 15 thousand to more than 43 thousand - an impressive number in a country of about 4 million inhabitants. The membership association Our Hajduk (Naš Hajduk - NH), which was originally formed in 2011 in an attempt to save the club from bankruptcy and meddling by local politicians, intensified and diversified its repertoire of activities, turning them overtly political. By doing that, it became not only the essential stakeholder in the club and Croatian football in general, but also the flag bearer for the movement of football supporters across Europe who are trying to turn football into a prime site of social and political contention. Whether by opposing the commercialisation of the sport and the detachment of clubs from their original communities, or by mobilising for or against various kinds of political forces and events, these supporters - as Dino Numerato (2018: 2) has argued - have given present-day football culture a "revolutionary spirit".

Football has arguably always been political - or at least had the potential of easily turning political. The contemporary evolution of a number of associations of football supporters into platforms with activist agendas is, however, a relatively new development. Unfortunately, we know little about the social foundations of their mobilisation. Where do political football activists come from? What are the characteristics of the social environments where they appear and successfully mobilise? Sociology of football has made significant strides in describing and explaining the evolving phenomena of football fandom and activism, but without much systematic empirical engagement with the question of social context. Part of the explanation for this lies in the field being dominated by in-depth ethnographic accounts which limit our ability to make broader conclusions. This study changes the methodological lens. It quantitatively analyses a unique dataset consisting of Our Hajduk membership figures and a host of socioeconomic, demographic, and political variables on the level of Croatia's 556 municipalities in order to relate the literature on the sociology of football fandom with the literatures on the social foundations of political participation and associational membership. 
The analysis demonstrates that the pattern of support for Our Hajduk, in addition to following the expected spatial, regional, and ethnic/national determinants of support which are embedded in the history of the club, also: 1) corresponds to the classical patterns of political participation and associational membership in other social fields and geographic and historical contexts; and 2) closely follows the patterns of political affiliation and participation in Croatia's electoral arena. More specifically, the pattern of support for Our Hajduk has a strong negative relationship with the pattern of support for the political forces which have dominated Croatian football for the past three decades and turned it into a social field marked by corruption and mismanagement. In Croatia, as in many other places, football is a site of political contention with patterns of participation not much different than other social fields.

\section{Social foundations of (political) football activism}

Football is rapidly changing. The changes on the pitch, the training ground, and in the boardroom have been matched by the changes in the stands. The sociology of football fandom has been preoccupied with two aspects of these changes. On the one hand, scholars have recognised the shifting demographics and loyalties of football supporters in response to the consumerisation, gentrification, and internationalisation of the game across the whole spectrum of countries (Kennedy and Kennedy, 2012; Millward, 2011). Football supporters are becoming more diverse based on their gender, class, and location not only in West European countries like the UK (Pope, 2011; Jewel et al., 2014; Perasović and Mustapić, 2017). The ties that bind football clubs to their communities - at least at the highest levels of the sport - are being profoundly transformed. On the other hand, many authors have also recognised the pushback to the consequences of commercialisation by a new class of supporters in a number of countries of different levels of economic development and football traditions - a kind of Polanyi's "double movement" Against Modern Football (Kennedy, 2013; Webber, 2015; Numerato, 2018). The commitment of these football supporters to the cause - from opposing takeovers of clubs by international investors (Dubal, 2010) to organising transnationally in order to enshrine the principles of supporters' participation in football governance (Kennedy and Kennedy, 2012) - has clearly crossed the 
boundaries of fandom and shifted firmly toward activism, though here we have to note that football supporters are becoming increasingly nuanced in their views of the structures of football governance and of the role to be played by supporters (García and Llopis-Goig, 2019).

While some question to which extent the activism of football supporters goes beyond the sociocultural domain of sport or fits into any sort of party politics (Cleland et al., 2018), its political character cannot be denied. Contemporary football supporter activists are political because they clearly aim to intentionally alter the existing relations of political power and bring about social change (Brough and Shresthova, 2012), even if their activities are often circumscribed by the domains of their clubs, local communities, or the sport. They do that through collective action which is often unmatched in numbers in any other sphere of political or social activism (Millward and Poulton, 2014). This collective action is fuelled by continuous mobilisation which is most often highly intensive because it strikes at the core of participants' social lives (Numerato, 2015). Indeed, football supporter activism is political exactly because it is directed at something that is much more than "a form of consumption" (Cleland et al., 2018: 16).

The political character of contemporary football supporter activists should not be surprising, considering the origins and nature of football clubs and their historical sources of popular support. Most football clubs are identity markers for their communities. They also provide structures and mechanisms through which many individuals - most often young men - get socialised into a collective: ethnic, national, class, or even religious or political (Mason, 1988). Actively participating in a community of football club supporters is for these people not a marginal experience, but a "regular, structuring part of their existence that enables them to feel belonging in the relative disorder of contemporary social formations" (Brown et al., 2008: 308). All of these defining characteristics of being a football supporter - identity, community, socialisation - are inherently political. Or, rather, they give football the potential for easy transformation from a relatively autonomous social field (Bourdieu, 1991) into a prime site of political contention particularly in times of crisis, whether on the level of individual clubs (García and Welford, 2015) or whole polities (Zaimakis, 2016; Cleland et al., 2018). 
Football clubs and football fandom are, however, human constructs, which means that their political nature is highly individualised. No two clubs shape or are shaped by two identical communities. If we look at the historical roots of most football clubs, we often note the tension or competition between two sets of social phenomena - class and nation (Giulianotti, 1999). This does not mean that clubs do not straddle these barriers, or that they do not draw support from a variety of social strata, or that their foundational sources of support cannot be based on regional, local, or religious identities. After all, football clubs are not like the potentially travelling franchises in American sports but are strongly tied to a defined geographic space. And these geographic spaces are often homes to demographically complex and changing communities. Nevertheless, it is fair to say that different clubs draw support from and symbolise different kinds of communities which may be defined geographically, nationally, or in class terms. The positioning of their supporters on any sort of spectrum - political or otherwise - can, therefore, vary dramatically from club to club (or even from terrace to terrace of the same stadium), as well as from the past to the present.

Although we must be cognisant of these idiosyncrasies inherent to all football clubs and their supporters, the empirical challenge before us remains. We need to answer the question: where do football supporters in general, and politically activist football supporters in particular, come from? In other words, what are the social conditions under which they are successfully recruited and mobilised? As Kevin Dixon has argued, much of the scholarship on football supporter culture classifies football supporters "as either products of social structures or agents of post-modernity" without much attempt at exposing the interplay between agency and structure (2012: 334). This is a fair assessment, but one that misses the fact that both ends of this theoretical range have limited empirical foundations. This, of course, does not mean that there have not been tremendously insightful, usually ethnographic, studies of football supporters which have given us a first-hand view into the origins of their fandom or even activism in different cultural contexts (e.g. Bleakney and Darby, 2018; Dixon, 2012; Dubal, 2010; Gilbert, 2018; Hodges, 2018; Lalić and Pilić, 2011; Totten, 2015). Exceptional advances have particularly been made by scholars 
employing relational sociology frameworks who have exposed the constant process of building and rebuilding of often transnational networks of football communities (Cleland et al. 2018). Nevertheless, the disciplinary methodological boundaries, as well as objective obstacles to data collection, have precluded generations of sociologists of sport from shedding systematic empirical light on the aforementioned question: where do (politically activist) football supporters come from?

If we accept the idea that supporter activism is a form of both cultural and political participation (Brough and Shresthova, 2012), which is the view espoused in this article, then that opens up the prospect of relating the literature on the sociology of football and sport fandom with the vast literatures on the politics and sociology of political participation, associational membership, and social movements. Does membership in football supporters' groups follow the same patterns as memberships in political organisations and various associations of the civil society? In two areas the findings of the two literatures should be largely in agreement. First, as argued above, being a football club supporter is decisively defined by spatial, national/ethnic, and regional belonging. The same can be said of political participation and associational membership as well, with a long strand of scholarship finding the patterns of these social phenomena dependent on the patterns of ethnic, national, or regional belonging, community size, and spatial distance (Curtis et al., 1992; Gallego, 2007; Morales, 2009). And second, in spite of recent evolution in this regard, football is a social field still strongly dominated by men, just as the levels of political participation and associational membership continue to be higher among men, despite contemporary shifts in trends in some polities (Burns et al., 1997; Dalton, 2013). Things get more complicated, however, when we consider other determinants of political participation such as education, socio-economic wellbeing, and political orientation. The fact that higher levels of education and socio-economic wellbeing lead to higher levels of political participation and associational membership is perhaps one of the strongest empirical findings in social science (Verba and Nie, 1972; Verba et al, 1993). In spite of a wave of scholarship demonstrating the broad appeal of football and the class and educational/professional diversity of the various coalitions and networks of activist supporters (Giulianotti, 2002; Cleland et al., 2018; Numerato, 2018), this relationship between educational 
and socio-economic performance and political activity is in tension with some of the classics of the sociology of football (Giulianotti, 1999: 40-47) and with the conventional popular view of the social foundations of football fandom.

Is football the favourite pastime dominantly in underprivileged communities? Similarly, do politically activist football supporters' groups mobilise more successfully in such communities, perhaps due to the increased commodification of football and the fact they are being priced out of their clubs' activities? Or do (politically activist) football supporters' groups thrive exactly in the same areas where most other social, civil, and political organisations thrive - i.e. among the more educated and more socioeconomically successful? Finally, and most intriguingly, what is the relationship between the patterns of being (politically activist) football supporters and the general patterns of political participation, particularly in cultural contexts where football is a highly politicised and contested social sphere? We simply do not know the answers to these questions. This is the case partly because contemporary sociology of football has largely focused on different issues, partly because it has remained disconnected from the literatures on social and political participation and associational membership, and partly because it has been dominated by methodological approaches which do not allow for empirically robust cross-case comparisons. Ethnographies of football fandom and activism have obviously been very useful tools of descriptive inference. In order to move beyond description, however, the field would benefit from - to borrow Sidney Tarrow's (1995) phrase - some "quantitative bones to its qualitative flesh."

\section{Our Hajduk and the struggle for clean football in Croatia}

Organised football supporters in post-communist Europe - particularly in Southeast Europe - are often perceived by their publics as violent nationalists with connections to various forms of criminal activity (Djordjević and Pekić, 2018). This is a tendency Andrew Hodges (2016) aptly labelled "nesting intra-orientalism" where the hooligans represent the internal Balkan other in a supposedly Europeanising society. While shaking this image off has proven difficult for many football supporters' groups when it comes to their portrayals in the popular press and media, 
recent academic literature paints a more nuanced picture of their motivations and strategies. Many authors have recognised the changing nature of the culture of football supporters in this region and the decreasing role of violence in their repertoire of activities. Scholars have also recognised the importance of temporal and social context in the unique, though related, paths football supporters' cultures have taken during the past two decades (Dubal, 2010; Kossakowski, 2017). Over the course of that time, we have witnessed an evolution of a number of different forms of football fandom in the region, perhaps none more noteworthy than the politically proactive football supporters' groups campaigning for their clubs, football, and politics to be clean of corruption and clientelism (Tregoures and Šantek, 2018). Among those groups, the association of supporters of Hajduk Split, Our Hajduk, has proven to be the most prominent and successful.

The association of supporters Our Hajduk grew out of the ultras supporters' group Torcida in 2011, at a time when the club was on the verge of bankruptcy with debts of more than $€ 15$ million after years of mismanagement by local political powerholders. Since the majority of the club shares were owned by the city of Split after the club's restructuring in 2008, Torcida organised a campaign of protests and public performances in order to pressure the city council to co-sign a $€ 4$ million loan to the club needed to avoid insolvency, as well as to organise elections for the club's supervisory board which would be open to active members of the new supporters' association (Lalić and Pilić, 2011). This was a controversial proposal strongly resisted by the local establishment which had used the club as a form of political capital. Nevertheless, Torcida and Our Hajduk succeeded in their demands, likely because politicians believed the debt-ridden and poorly managed club was no longer a resource worth fighting for. The club was thus saved and set on the slow and painful course toward financial recovery. This story of supporters organising in reaction to club crisis and mismanagement is in many ways typical of similar supporter associations in other cultural contexts (García and Welford, 2015). Nevertheless, it is notable for the success of active or activist supporters at overcoming the apathy of a generally passive and disillusioned body of fans which has hampered supporters' achievements at other clubs (Cleland and Dixon, 2015). 
From these ad hoc crisis-driven roots, however, Our Hajduk grew into an association with a much broader agenda. To use Herbert Blumer's terminology, applied by Millward and Poulton (2014) to great effect in their study of F.C. United of Manchester supporters, Our Hajduk passed from its social movement stage of unrest to the stage of "formalization". Its leadership is staffed by highly educated and professionally successful supporters who thus defy the popular stereotypes associated with football supporters in the region. The association fought against its passive status vis-à-vis club management and acquired the most active stakeholder role possible (Cleland 2010). It held three rounds of elections to the club supervisory board - in 2011, 2015, and 2018 - and embarked on a still-ongoing campaign for the acquisition of club shares (in $2019 \mathrm{NH}$ holds about $25 \%$ of Hajduk shares), giving the association status not only as a stakeholder, but also as the second largest official club shareholder after the city of Split which holds $65 \%$ of the shares. In other words, within several years, Our Hajduk members transformed their position in club management from passive to active, and their status in the life of the club from that of customers to that of stakeholders and shareholders (García and Welford, 2015). After several years under $\mathrm{NH}$-elected supervisory boards and new club management, the club's debts were finally paid off largely with income from transfers of young players and, as mentioned above, the membership in the supporters' association skyrocketed to more than 43 thousand in 2016, even though Hajduk did not enjoy much sporting success.

Of course, not all 43 thousand members joined the $\mathrm{NH}$ for the same reasons or with the same level of commitment. For example, about 5 thousand members took part in the 2018 elections for the club supervisory board, and Hajduk's home attendance - though by far the highest in Croatia's First League - hovers at around 11 thousand. In some respects, NH could be considered as a form of a "tertiary association" where a mix of some active and mostly passive members share ties to common symbols or ideals, but not necessarily to each other (Putnam, 1995). Moreover, membership in $\mathrm{NH}$ has in many ways become synonymous with support for the club (though the relationship does not work vice-versa as well, i.e. a substantial minority of Hajduk supporters are not supporters of $\mathrm{NH}$ or its platform), so disentangling one from the other is virtually impossible. Nevertheless, considering the clearly political nature of the NH platform, its 
ability - together with Torcida - to draw huge crowds when needed as in the case of the 2014 protest, and the repertoire of its activities, the empirical value in explaining the level of its support remains.

Because, the activities of Our Hajduk have not been limited to managing the elections to the club supervisory board or the acquisition of club shares. Hajduk competes in a league run by the Croatian Football Association which is notorious for corruption on all levels. The HNS institutions, including the referee organisation whose leaders have been convicted to multi-year sentences for match fixing and extortion in 2014 and 2017 (Jakelić, 2017), have been strongly dominated by the cadre recruited by Croatia's largest party, the Croatian Democratic Union (HDZ), and loyal to the ruler of Hajduk's principal rival Dinamo Zagreb, Zdravko Mamić. Mamić has also been convicted in 2018 to a multi-year sentence for tax evasion and transfer fraud but avoided arrest by escaping to Bosnia and Herzegovina (Patković, 2018). This intertwining of political influence of the HDZ (which has dominated most HNS administrations since Croatia's independence) and the financial interests of Zdravko Mamić and his network of associates has been the staple of Croatian football during the past decade and a half (Lalić, 2018; Vukušić and Miošić, 2018). It was also the principal target of Our Hajduk legal actions and protest campaigns directed at the public, media, and state institutions, which culminated in the active participation of $\mathrm{NH}$ members and legal experts in the drafting of the new Law on Sport (Tregoures and Šantek, 2018). The Law was officially promulgated in 2015 by the parliament dominated by the Social Democratic Party (SDP) and with strong HDZ opposition (Hrvatski Sabor, 2015). The law was supposed to free sports associations and clubs from political meddling and to bring transparency to their financial operations. Although it proved to be largely toothless, the law solidified the image of $\mathrm{NH}$ and Torcida as champions of sport and politics clean of corruption and clientelism both domestically and abroad. It also solidified their image as the only force strong enough to stand up to the HDZ - which went on to form the government after the 2015 and 2016 parliamentary elections - in such an important site of political contention as football. 


\section{Data, method, and empirical propositions}

As mentioned above, Our Hajduk was formed in 2011, but the critical period in its existence was the year after the November 2014 protest. That is when the association took over the running of the membership operations from the football club and, as a result, its membership for 2016 went from about 15 thousand to more than 43 thousand. In early 2017, the NH leadership allowed access to an anonymised list of its members. Access was granted because the $\mathrm{NH}$ itself wanted to better understand the geographic pattern of its support. 34,521 members were established to be residents of Croatia and were allocated to one of Croatia's 556 municipalities based on their place of residence. Their geographic distribution, shown in Figure 1, demonstrates that NH is strongest in Dalmatia, while notably present in all regions of Croatia.

\section{[Figure 1 about here]}

In the Croatian context, municipalities are the smallest geographic units on which a wealth of economic, political, and sociodemographic data is collected. With the median population of just under 3000 and the extensive level of administrative power they have, municipalities represent the foundational building blocks of Croatian social organisation and are meaningful communities in the truest sense of that word. This makes them the most ideal units of analysis for this study. Quantitative analyses of aggregate-level data have been a staple of research in virtually all social sciences - from the study of economic development, through the study of elections, to the study of membership in various associations such as labour unions. Here it is important to note that while quantitative analyses of aggregate-level data are ideal as means of modelling socioeconomic, demographic, spatial, or temporal context, their results should not be mistaken for individual-level findings. In other words, we need to be cognisant of the perils of ecological fallacy, while recognising that the design of this study and the data available are arguably perfectly suited for the questions posed by this article.

Identifying potential contextual determinants of support for an association of supporters of a football club (politically activist or not) is clearly contingent on the club's history and social status 
which varies dramatically from club to club. Being cognisant of the contextual realities of Hajduk Split and its supporters, as well as limitations of available data, a set of explanatory variables here listed in Table 1 - was chosen and collected from the Croatian Bureau of Statistics, the Tax Authority, and the State Electoral Commission. They represent the most comprehensive way of addressing the research questions and may offer guidance in understanding the contextual dynamics of support for a football club like Hajduk Split, as well as for an association like Our Hajduk which has a clear social and political agenda.

[Table 1 about here]

The first four explanatory variables on that list - Poljud distance, Maksimir distance, Dalmatians, and Football generation - can be thought of as the geographic and demographic baseline, capturing the dualist nature of Croatia's football "market" (i.e. the dominance of the rivalry between Hajduk Split and Dinamo Zagreb) and the principal target population of Hajduk supporters: young men and those born in Dalmatia.

The following batch of five explanatory variables - Settlement size, Croats, Religious, Education, and War - capture some of the most studied socio-demographic factors influencing different types of political participation and associational membership. Here the assumption is that the levels of NH membership would be negatively related with the size of communities, consistent with findings in other social contexts (Curtis et al., 1992); positively related to the proportion of Croats in the municipal population considering Hajduk's strong connection to Croatian identity and ethnic minorities exhibiting lower levels of political participation and associational membership (Diehl and Blohm, 2001; Leighley and Vedlitz, 1999; Gallego, 2007); positively related to the level of education in the municipality considering the clearly positive influence of education on associational membership and political participation, regardless of social or historical context (Hillygus, 2005; Mayer, 2011), and considering the nature of the NH social and political message; and negatively related to the communities' exposure to war violence, likely due to the torn ties 
of social inclusion and involvement and due to greater levels of overall social malaise and apathy (Glaurdić and Vuković, 2016a).

Two variables capture the economic wellbeing of the municipal population - Income and Unemployment. Stronger job market performance and general affluence have been shown to be mostly conducive to higher levels of political participation and associational membership (Verba, Schlozman, and Brady, 1995; Curtis et al., 2001). Moreover, the annual NH membership fee of 100 Croatian kunas (about €13) does not present a real barrier to entry even for the most financially challenged potential members. The expectation here - in contrast to the popular misconception of football being the preferred pastime in economically disadvantaged areas and an outlet for this population's social and economic frustrations - is that at least Unemployment would be negatively related to NH membership as higher rates of unemployment can lead to withdrawal from political and associational activity due to apathy and a diminished sense of political efficacy (Gallego, 2008).

Football is, despite recent shifts, still a male-dominated sport, particularly when it comes to the deeply committed supporters. The interaction between gender, family, and football is, however, an empirically under-researched question. Do (predominantly male) football supporters come from areas with strong traditional gender roles and family structures? Modelling these dynamics with census data is difficult. Here we use four variables which capture the state of gender roles and the prevalence of and commitment to traditional family structures: Dissimilarity index, Female workforce, Married, and Referendum "No". Three things need to be noted here. First, gender occupational dissimilarity, captured by Dissimilarity index, has been shown to be a solid predictor of the population's opposition to progressive views of gender roles and family structures and ideologically conservative politicians (McVeigh and Sobolewski, 2007; McVeigh and Diaz, 2009). Second, the variable Married is a standard measure of the prevalence of traditional family structures and a solid predictor of higher levels of associational membership (Morales, 2009). And third, the variable Referendum "No" represents the proportion of the municipality's adult population which voted against the constitutional definition of marriage as a 
union between a man and a woman in Croatia's 2013 referendum promoted by rightist groups (Glaurdić and Vuković, 2016b). This variable perfectly captures the dividing line between the traditionalist and progressive views of gender and family. Conventional view of football supporters - in the case of Hajduk grounded also in a history of homophobic actions by the members of Torcida (Perasović and Mustapić, 2017) - would suggest that Our Hajduk should be positively related to Dissimilarity index and Married, while negatively related to Female workforce and Referendum "No".

Although a non-partisan association of supporters of a football club, Our Hajduk - in contrast to many similar associations in Europe, particularly in the UK (Cleland et al. 2018) - ultimately is an organisation with a clear social and political agenda that goes beyond football. It is thus imperative to establish to which extent its pattern of support corresponds to the general pattern of political participation and allegiance of the Croatian population. Fortunately, as NH was running its large membership campaign throughout 2016, Croatia was in a political crisis which culminated with the national parliamentary election in September of that year. Croatian parties do not fit neatly into ideological moulds, especially when it comes to economic policy. However, they are clearly delineated when it comes to their attitudes toward sport, with the HDZ being the only major electoral competitor actively defending the corrupt status quo in Croatian football. The variable HDZ vote thus represents the proportion of votes won by the HDZ in the 2016 elections. The expectation would be that the pattern of its support is negatively related to the pattern of NH membership, in spite of the fact that the region of Dalmatia is actually one of HDZ's traditional strongholds.

We also add the variables Turnout and Invalid vote as proxies for the general state of political participation and interest of the local population. Turnout is the standard measure of political participation (Cox, 2015), whereas the proportion of invalid ballots has recently been identified as an appropriate measure of voter anger and displeasure with the party system offerings (Moral, 2016). Our expectation here would be that Turnout would have an influence on NH membership which would be conditional on party allegiances. The NH should not do well in areas with highly 
motivated HDZ voters, but it should do well in areas with highly motivated anti-HDZ voters. Similarly, considering that NH membership is a form of expression of faith that something can be changed, the expectation would be that NH membership would have a negative relationship with Invalid vote as it is a sign of a more destructive, rather than constructive, attitude toward politics. The descriptive statistics of all variables are shown in Table 2.

[Table 2 about here]

Since the dependent variable, NH members, is a proportional variable distributed on a unit interval $(0,1)$, ordinary least squares (OLS) was not an option. Instead, what is employed is the fractional logit model recommended by Papke and Wooldridge (1996) which is attractive because it requires no transformations of data at the extreme values and provides the best fit for the tested models. Heteroscedasticity is controlled for by applying a robust estimation of standard errors and possible problems of multicollinearity are dealt with by computing variance inflation factors (VIF) for all explanatory variables. Their values are well below the maximum recommended value of 10 (Marquardt, 1970), with the mean value of 3.4.

Lack of multicollinearity notwithstanding, determining the effects of the four different clusters of explanatory variables (socio-demographic, economic, family/gender, and political) is a challenge because all these variables are intertwined and connected. This can be particularly problematic when disentangling the effects of the political cluster of variables which can be argued to be causally "shallower" than the socio-demographic or the economic (Kitschelt, 2003). This is why, in addition to employing the full model with all explanatory variables, what is also tested is the impact of the four different clusters independently (always including the geographic and demographic baseline). This approach does not expose the mechanism behind the pattern of $\mathrm{NH}$ mobilisation, but it is the most appropriate methodological approach if we wish to understand the comparative explanatory power of the four clusters of independent variables. 


\section{Results and interpretations}

The results of the analyses are presented in Table 3, with each column representing one of the seven models: 1) the model using baseline demographic variables which are also the foundation for all other models, 2) the model highlighting the five socio-demographic variables, 3) the economic model highlighting the effects of economic wellbeing, 4) the model capturing the effects of variables related to gender and family, 5) the model relating the pattern of $\mathrm{NH}$ membership to the pattern of political/electoral participation, 6) a variant of the political participation model highlighting the interactive effect of turnout and political orientation, and finally 7) the full model. The table reports average marginal effects because of their easier and more useful interpretation, since they predict the change in dependent variable as a unit change in the independent variable (Angrist and Pischke, 2009: 103).

\section{[Table 3 about here]}

The results of all models immediately make it clear that the choice of the four baseline variables - Poljud distance, Maksimir distance, Dalmatians, and Football generation - was a sensible one. These four variables are statistically significant on the $1 \%$ level in the expected direction 26 out of 28 times. In the interpretation of the effect sizes, it is most prudent to use the variables' standard deviation figures, here presented in Table 2. Looking at the baseline Model 1, we can say that one standard deviation increase in the distance of the municipal centre from the Hajduk stadium (i.e. $89.79 \mathrm{~km}$ ) implies 3.3 fewer NH members per 1000 municipal inhabitants. The same one deviation increase in the distance from the Dinamo Zagreb stadium $(87.37 \mathrm{~km}$ ) leads to 4 additional NH members per 1000 municipal inhabitants. One deviation increase in the number of municipal inhabitants born in Dalmatia, on the other hand, results in 4.8 additional NH members, and a similar increase in the proportion of young men in the municipal population leads to 1.2 extra NH members per 1000 municipal inhabitants. The average number of NH members per 1000 municipal inhabitants is 8.7 , so these effects can be considered as quite substantial. Since coefficients for these four variables do not vary dramatically across all seven models, we can say that these baseline model effects are a rather solid overall estimate, and with the $R^{2}$ value of 
0.553 , we can also say that the baseline model does reasonably well in explaining the pattern of $\mathrm{NH}$ support. In other words, this pattern is - as expected - highly contingent on space and the demographic supply of 'raw material' needed for a successful association of football supporters.

The overall strength of the baseline model notwithstanding, however, the remaining six models all offer important insights and improvements. In the socio-demographic Model 2, we can find support for our three propositions regarding the effects of the size of community, ethnic belonging, and education on the level of $\mathrm{NH}$ membership. The level of support for $\mathrm{NH}$ is - as expected - higher in smaller communities, communities with fewer ethnic minorities, and communities with a better educated population. In line with Hajduk's strong association with Croatian national heritage and in line with the literature on the sociology of political participation of ethnic minorities (Diehl and Blohm, 2001; Leighley and Vedlitz, 1999; Gallego, 2007), Our Hajduk enjoys higher levels of support in municipalities with higher proportions of ethnic Croats. In contrast to popular notions of the pattern of support for football clubs, $\mathrm{NH}$ enjoys higher support exactly in communities whose inhabitants perform better on the education measure. This finding is also supported in the economic Model 3, where the level of $\mathrm{NH}$ support is negatively related to unemployment. If we use the coefficients in models 2 and 3 , we can say that one standard deviation increase in education leads to 1.7 additional $\mathrm{NH}$ members, and one standard deviation decrease in the rate of unemployment leads to 3.4 additional NH members per 1000 municipal inhabitants. Simply put, the pattern of support for Our Hajduk follows the general pattern of associational membership and participation identified in a variety of other social fields. It does not correspond to the commonly held stereotypes of football supporters coming from socioeconomically and educationally underprivileged communities.

Model 4, on the other hand, tests the relationship between the pattern of NH membership and the variables capturing gender and family dynamics in Croatian municipalities. Two variables capturing traditional gender roles - Dissimilarity index and Female workforce - remain insignificant, suggesting that $\mathrm{NH}$ supporters do not come from communities disproportionately marked by economic gender segregation. On the other hand, two variables capturing family 
relations do reach statistical significance on the $1 \%$ level and have substantively important effects. One standard deviation increase in the proportion of married people in the adult population leads to 2.2 additional NH members per 1000 municipal inhabitants. More interestingly, one standard deviation increase in the vote against the constitutional definition of marriage as a union between a man and a woman in the 2013 referendum leads to 2.6 additional NH members. In other words, Our Hajduk succeeds in communities with traditional family structures, but whose inhabitants actively oppose socially regressive family policies. The higher level of $\mathrm{NH}$ support in municipalities with higher proportions of married inhabitants is in line with the literature's findings on the greater incidence of associational membership among married adults (Morales, 2009). The close relationship with the 2013 referendum findings, on the other hand, provides an important caveat to the narratives of football supporters and homophobia even though it is likely a signifier of the fact that the referendum campaign was heavily politicised and that it reflected the standing political cleavages between the principal political parties (Glaurdić and Vuković, 2016b).

This interpretation is indeed borne out by the findings presented in models 5 and 6 . As Model 5 shows, the membership in Our Hajduk is negatively related to the level of support for the HDZ. Moreover, it is negatively related to the proportion of invalid votes. As hypothesised in the previous section, $\mathrm{NH}$ membership is not only a sign of support for Hajduk, but also a form of expression of faith that something can be changed in the club and in Croatian football which has been dominated by the toxic influence of the HDZ. Since the spoiling of ballots is a sign of a more destructive attitude toward politics (Moral, 2016), Model 5 supports the proposition that membership in NH is a form of constructive opposition to the HDZ. Model 6, on the other hand, goes even further in demonstrating the close connection in the pattern of $\mathrm{NH}$ support with the pattern of conventional political participation in Croatia. It shows that the relationship between the HDZ vote and NH membership is conditional on turnout. In other words, where the vote for HDZ is low - higher turnout/political participation has a positive impact on NH membership. And where the vote for the HDZ is high - higher turnout/political participation has a negative impact on NH membership. 
Most importantly, this relationship 'survives' in the full model which boasts a solid $R^{2}$ of 0.687 . As can be observed from Model 7 results, in addition to the baseline variables capturing space and regional belonging, only the variables Croats and Unemployment remain statistically significant, together with the conditional relationship between Turnout and HDZ vote. Therefore, we can safely say that the geographic pattern of support for NH primarily depends on: 1) spatial closeness to Hajduk Split and its principal rivals Dinamo Zagreb, 2) Dalmatian and Croatian identity of the local population, 3) economic wellbeing of the local population, and 4) the pattern of political participation and affiliation with the HDZ. To better understand the exact nature of this relationship of NH membership to the pattern of political/electoral participation and affiliation, Figure 2 shows the marginal effects of turnout on $\mathrm{NH}$ membership conditional on the level of support for the HDZ. The results are clear: Our Hajduk thrives in areas with mobilised anti-HDZ voters, and it struggles in areas with mobilised HDZ voters. Simply put, the NH is an association

of football supporters whose clear political agenda for football, sports, and politics clear of corruption and clientelism attracts and repels people from communities with distinct political commitments.

[Figure 2 about here]

\section{Conclusions and directions for future research}

The aim of this article was to identify the social context under which (politically activist) football supporters are successfully recruited and mobilised. More specifically, the aim was to answer whether the pattern of support for a football club like Hajduk Split or an association of football supporters like Our Hajduk follows the patterns of associational membership in other social spheres, or whether it conforms to the commonly held and biased views of where football supporters come from. The aim was also to establish whether support for a football club supporter association can be seen as a form of political or politicised activity. Aggregate-level data analysis has its limitations and we must be careful not to fall into the traps of ecological fallacy and extrapolate individual-level conclusions from our findings. Moreover, the limited nature of Our Hajduk membership data does not allow us to make more nuanced conclusions about the 
motivations and commitments of different $\mathrm{NH}$ members. Regardless of these limitations, however, the article's principal aims have been fulfilled.

First, the analysis shows that the pattern of support for Our Hajduk follows the patterns of associational membership in other social spheres and different geographical and historical contexts. In agreement with a long line of research on associational membership, the analysis presented here shows that the level of support for Our Hajduk has a clearly positive relationship with the communities' level of education, socioeconomic well-being, as well as presence of the society's ethnic/national majority. In contrast to common stereotypes of football supporters' communities and some of the classics of the sociology of football, we can say that at least this football supporters' group thrives exactly in the same areas where most other social, civil, and political organisations thrive - i.e. among the more educated and more socioeconomically successful.

And second, the pattern of support for Our Hajduk clearly suggests that its membership can indeed be seen as a form of political or politicised activity. The analysis shows that the level of NH support has a negative relationship with the proportion of spoiled ballots in Croatia's elections. This implies that Our Hajduk succeeds where people believe in constructive opposition to the political powerholders. More importantly, the NH membership figures also have a negative relationship with the level of support for the Croatian Democratic Union - the party which has dominated Croatian football for the past three decades and helped turn it into a hotbed of corruption. This relationship is additionally conditioned by the level of electoral turnout, which means that the pattern of $\mathrm{NH}$ support closely follows the complex pattern of political participation and affiliation in Croatian electoral politics. In other words, the pattern of support for NH suggests that membership in this association can be seen as an active expression of constructive opposition to the system of crony capitalism the HDZ has built in football and beyond.

Research presented in this article must be supplemented by solid research on the individual level which would expose the dynamics of allegiance to a politically activist football supporters' group 
such as Our Hajduk in complete detail. Nevertheless, the benefits of the methodological approach employed here are obvious. It has allowed us to make more general and reliable conclusions, and it has opened more direct lines of communication between the literature on the sociology of football and the broader literatures on associational membership and political participation. The lessons of this study for our understanding of the evolution of football fandom and activism can and should be tested in other social and geographic contexts. A wealth of new forms of largescale data on supporters' and activists' interaction with football and politics is being generated daily. If we wish to move beyond descriptive inference and truly grasp the role football plays in contemporary societies, we must diversify our methodological toolbox and use all the opportunities these data offer. Sociology of football fandom can only benefit from adding some "quantitative bones" to its body of scholarship built almost exclusively by qualitative methods. 


\section{References}

Alač, Z (2014) Poslušajte govor navijača Bena. Index.hr. 1 December. Available at: https://www.index.hr/sport/clanak/Poslusajte-govor-navijaca-Bena-Nasim-nogometomvladaju-kralj-njegova-obitelj-i-huligani-u-odijelima/787355.aspx (Accessed on 15 March 2019).

Angrist JD and Pischke J-S (2009) Mostly Harmless Econometrics: An Empiricist's Companion. Princeton, NJ: Princeton University Press.

Bleakney J and Darby P (2018) The pride of east Belfast: Glentoran Football Club and the (re)production of Ulster unionist identities in Northern Ireland. International Review for the Sociology of Sport 53(8): 975-996.

Bourdieu P (1991) Sport and social class. In: Mukerji C and Schudson M (eds.) Rethinking Popular Culture: Contemporary Perspectives in Cultural Studies. Berkeley: University California Press, pp. 357-373.

Brough M and Shresthova S (2012) Fandom meets activism: Rethinking civic and political participation. Transformative Works and Cultures 10.

Brown A, Crabbe T, and Mellor G (2008) Introduction: Football and community - practical and theoretical considerations. Soccer \& Society 9(3): 303-312.

Burns N, Schlozman KL and Verba S (1997) The public consequences of private inequality: Family life and citizen participation. American Political Science Review 91(2): 373-389.

Cleland J (2010) From passive to active: The changing relationship between supporters and football clubs. Soccer \& Society 11(5): 537-552.

Cleland J and Dixon K (2015) 'Black and whiters': The relative powerlessness of 'active' supporter organization mobility at English Premier League football clubs. Soccer \& Society 16(4): 540-554.

Cleland J, Doidge M, Millward P, and Widdop P (2018) Collective Action and Football Fandom: A Relational Sociological Approach. Cham, Switzerland: Palgrave Macmillan.

Cox GW (2015) Electoral rules, mobilization, and turnout. Annual Review of Political Science 18: 49-68.

Curtis JE, Grabb EG and Baer DE (1992) Voluntary association membership in fifteen countries: A comparative analysis. American Sociological Review 57(2): 139-152.

Curtis JE, Baer DE and Grabb EG (2001) Nations of joiners: Explaining voluntary association membership in democratic societies. American Sociological Review 66(6): 783-805.

Dalton RJ (2013) Citizen Politics: Public Opinion and Political Parties in Advanced Industrial Democracies. Thousand Oaks, CA: CQ Press.

Diehl C and Blohm M (2001) Apathy, adaptation or ethnic mobilisation? On the political attitudes of an excluded group. Journal of Ethnic and Migration Studies 27(3): 401-420.

Dixon K (2012) Learning the game: Football fandom culture and the origins of practice. International Review for the Sociology of Sport 48(3): 334-348.

Djordjević I and Pekić R (2018) Is there space for the left? Football fans and political positioning in Serbia. Soccer \& Society 19(3): 355-372.

Dubal S (2010) The neoliberalization of football: Rethinking neoliberalism through the commercialization of the beautiful game. International Review for the Sociology of Sport 45(2): 123-146. 
Gallego A (2007) Unequal political participation in Europe. International Journal of Sociology 37(4): 10-25.

García B and Llopis-Goig R (2019) Club-militants, institutionalists, critics, moderns and globalists: A quantitative governance-based typology of football supporters. International Review for the Sociology of Sport, online first.

García B and Welford J (2015) Supporters and football governance, from customers to stakeholders: A literature review and agenda for research. Sport Management Review 18(4): 517-528.

Gilbert A (2018) Tri vjere, jedna nacija, država Tuzla! Football fans, political protest and the right to the city in postsocialist Bosnia-Herzegovina. Soccer \& Society 19(3): 373-399.

Giulianotti R (1999) Football: A Sociology of the Global Game. Cambridge, UK: Polity Press.

Giulianotti R (2002) Supporters, followers, fans, and flaneurs: A taxonomy of spectator identities in football. Journal of Sport \& Social Issues 26(1): 25-46.

Glaurdić J and Vuković V (2016a) Voting after war: Legacy of conflict and the economy as determinants of electoral support in Croatia. Electoral Studies 42: 135-145.

Glaurdić J and Vuković V (2016b) Proxy politics, economic protest, or traditionalist backlash: Croatia's referendum on the constitutional definition of marriage. Europe-Asia Studies 68: 803-825.

Hillygus DS (2005) The missing link: Exploring the relationship between higher education and political engagement. Political Behavior 27(1): 25-47.

Hodges A (2016) The hooligan as 'internal' other? Football fans, ultras culture and nesting intraorientalisms. International Review for the Sociology of Sport 51(4): 410-427.

Hodges A (2018) Fan Activism, Protest and Politics: Ultras in Post-Socialist Croatia. Abingdon, UK: Routledge.

Hrvatski Sabor (2015) Zakon o izmjenama i dopunama zakona o sportu. Narodne novine. 85, 1 August.

Jakelić I (2017) Željko Širić pravomoćno je osuđen na četiri godine zatvora. Večernji list. 18 July. Available at https://www.vecernji.hr/vijesti/zeljko-siric-pravomocno-osudjen-1183561 (accessed 10 February 2019).

Jewell RT, Simmons R and Szymanski S (2014) Bad for business? The effects of hooliganism on English professional football clubs. Journal of Sports Economics 15(5): 429-450.

Jones-Correa MJ and Leal DL (2001) Political participation: Does religion matter? Political Research Quarterly 54(4): 751-770.

Kennedy D (2013) A contextual analysis of Europe's ultra football supporters movement. Soccer \& Society 14(2): 132-153.

Kennedy P and Kennedy D (2012) Football supporters and the commercialization of football: Comparative responses across Europe. Soccer and Society 13(3): 327-340.

Kitschelt $\mathrm{H}$ (2003) Accounting for outcomes of post-communist regime diversity: What counts as a good cause? In: Ekiert G and Hanson S (eds) Capitalism and Democracy in Central and Eastern Europe. New York, NY: Cambridge University Press.

Kossakowski R (2017) From communist fan clubs to professional hooligans: A history of Polish fandom as a social process. Sociology of Sport Journal 34(3): 281-292.

Lalić D (2018) Nogomet i politika: Povijest i suvremenost međuodnosa u Hrvatskoj. Zagreb: Fraktura. 
Lalić D and Pilić D (2011) Torcida: Pogled iznutra. Zagreb: Profil.

Leighley JE and Vedlitz A (1999) Race, ethnicity, and political participation: Competing models and contrasting explanations. Journal of Politics 61(4): 1092-1114.

Marquardt DW (1970) Generalized inverses, ridge regression and biased linear estimation. Technometrics 12.

Mason T (1988) Sport in Britain. London: Faber \& Faber.

Mayer AK (2011) Does education increase political participation? Journal of Politics 73(3): 633645.

McVeigh R and Sobolewski J M (2007) Red counties, blue counties and occupational segregation by sex and race. American Journal of Sociology 113(2): 446-506.

McVeigh R and Diaz M E D (2009) Voting to ban same-sex marriage: Interests, values, and communities. American Sociological Review 74(6): 891-915.

Millward P (2011) The Global League: Transnational Networks, Social Movements and Sport in the New Media Age. Basingstoke: Palgrave Macmillan.

Millward P and Poulton G (2014) Football fandom, mobilisation and Herbert Blumer: A social movement analysis of F.C. United of Manchester. Sociology of Sport Journal 31(1): 1-22.

Moral M (2016) The passive-aggressive voter: The calculus of casting an invalid vote in European democracies. Political Research Quarterly 69(4): 732-745.

Morales L (2009) Joining Political Organisations: Institutions, Mobilisation and Participation in Western Democracies. Colchester, UK: ECPR Press.

Numerato D (2015) Who says "no to modern football?" Italian supporters, reflexivity, and neoliberalism. Journal of Sport and Social Issues. 39(2): 120-138.

Numerato D (2018) Football Fans, Activism and Social Change. Abingdon, UK: Routledge.

Patković N (2018) Zdravko Mamić osuđen na šest i pol godina zatvora! Jutarnji list. 6 June. Available at: https://www.jutarnji.hr/vijesti/crna-kronika/zdravko-mamic-osuden-na-sesti-pol-godina-zatvora-braca-mamic-vrbanovic-te-poreznik-pernar-proglaseni-krivima-zaizvlacenje-novca-iz-dinama/7441848/ (accessed 10 February 2019).

Perasović B and Mustapić M (2017) Carnival supporters, hooligans, and the 'Against Modern Football' movement: Life within the ultras subculture in the Croatian context. Sport in Society 20(7): 121-136.

Pope S (2011) Like pulling down Durham Cathedral and building a brothel. International Review for the Sociology of Sport 46(4): 471-487.

Putnam RD (1995) Bowling alone: America's declining social Capital. Journal of Democracy 6(1): $65-78$.

Tarrow S (1995) Bridging the quantitative-qualitative divide in political science. American Political Science Review 89(2): 471-474.

Totten M (2016) Football and community empowerment: How FC Sankt Pauli fans organize to influence. Soccer \& Society 17(5): 703-720.

Tregoures $L$ and Šantek G (2018) A comparison of two fan initiatives in Croatia: Zajedno za Dinamo (Together for Dinamo) and Naš Hajduk (Our Hajduk). Soccer \& Society 19(3): 453464.

Verba S and Nie NH (1972) Participation in America: Political Democracy and Social Equality. New York: Harper and Row. 
Verba S, Schlozman, KL and Brady HE (1995). Voice and Equality: Civic Voluntarism in American Politics. Cambridge, MA: Harvard University Press.

Verba S, Schlozman KL, Brady HE and Nie NH (1993) Citizen activity: Who participates? What do they say? American Political Science Review 87(2): 303-318.

Vukušić $D$ and Miošić $L$ (2017) Reinventing and reclaiming football through radical fan practices? NK Zagreb 041 and Futsal Dinamo. Soccer \& Society, 19(3): 440-452.

Webber DM (2015) 'Playing on the break': Karl Polanyi and the double-movement 'Against Modern Football'. International Review for the Sociology of Sport 52(7): 875-893.

Zaimakis $Y$ (2016) Football fan culture and politics in modern Greece: The process of fandom radicalization during the austerity era. Soccer \& Society 19(2): 252-270. 
Table 1. Variables used

\begin{tabular}{|c|c|}
\hline Variable & Description \\
\hline $\mathrm{NH}$ members & Proportion of the population who are members of Naš Hajduk. \\
\hline Poljud distance & $\begin{array}{l}\text { Distance in km of the municipal center from the Poljud Stadium of HNK } \\
\text { Hajduk Split. }\end{array}$ \\
\hline Maksimir distance & $\begin{array}{l}\text { Distance in km of the municipal center from the Maksimir Stadium of GNK } \\
\text { Dinamo Zagreb. }\end{array}$ \\
\hline Dalmatians & Number of people born in Dalmatia, per 1000 inhabitants (In). \\
\hline Football generation & Proportion of the population who are men aged $15-39$. \\
\hline Settlement size & Weighted average settlement size in municipality (In). \\
\hline Croats & Proportion of the population who are Croats. \\
\hline Religious & $\begin{array}{l}\text { Proportion of the population who identify themselves as members of any } \\
\text { religious group. }\end{array}$ \\
\hline Education & Average number of years of education for population older than 15. \\
\hline War & $\begin{array}{l}\text { Number of people who are disabled and whose cause of disability was the } \\
1991-1995 \text { war for independence, per } 1000 .\end{array}$ \\
\hline Income & Average monthly net income in Croatian kunas (In). \\
\hline Unemployment & Rate of municipal unemployment. \\
\hline Dissimilarity index & Index of gender occupational dissimilarity. \\
\hline Female workforce & Proportion of municipal workforce which is female. \\
\hline Married & Proportion of adult population who are married. \\
\hline Referendum “No" & $\begin{array}{l}\text { Proportion of adult population which voted "No" in the } 2013 \text { referendum on } \\
\text { the constitutional definition of marriage. }\end{array}$ \\
\hline HDZ vote & Proportion of the 2016 parliamentary vote won by HDZ. \\
\hline Turnout & Turnout in the 2016 parliamentary election. \\
\hline Invalid votes & Proportion of invalid ballots in the 2016 parliamentary election. \\
\hline
\end{tabular}


Table 2. Descriptive statistics

\begin{tabular}{|c|c|c|c|c|}
\hline Variable & Mean & SD & Min & Max \\
\hline $\mathrm{NH}$ members & 0.009 & 0.017 & 0 & 0.151 \\
\hline Poljud distance & 216.52 & 89.79 & 1.56 & 334.43 \\
\hline Maksimir distance & 148.27 & 87.37 & 2.82 & 400.40 \\
\hline Dalmatians & 3.033 & 2.237 & 0 & 6.886 \\
\hline Football generation & 0.158 & 0.016 & 0.067 & 0.200 \\
\hline Settlement size & 6.923 & 1.250 & 3.810 & 13.310 \\
\hline Croats & 0.889 & 0.171 & 0.018 & 1 \\
\hline Religious & 0.965 & 0.037 & 0.768 & 1 \\
\hline Education & 9.849 & 0.872 & 5.925 & 12.132 \\
\hline War & 15.38 & 12.54 & 0 & 103.08 \\
\hline Income & 7.522 & 0.265 & 6.315 & 8.086 \\
\hline Unemployment & 0.155 & 0.093 & 0.025 & 0.495 \\
\hline Dissimilarity index & 0.347 & 0.064 & 0.128 & 0.525 \\
\hline Female workforce & 0.416 & 0.041 & 0.208 & 0.506 \\
\hline Married & 0.812 & 0.035 & 0.684 & 0.905 \\
\hline Referendum “No" & 0.084 & 0.051 & 0.006 & 0.262 \\
\hline HDZ vote & 0.392 & 0.158 & 0 & 0.859 \\
\hline Turnout & 0.517 & 0.060 & 0.325 & 0.790 \\
\hline Invalid votes & 0.024 & 0.011 & 0.005 & 0.128 \\
\hline
\end{tabular}


Table 3. Analysis results

\begin{tabular}{|c|c|c|c|c|c|c|c|}
\hline & $\begin{array}{c}(1) \\
\text { Baseline }\end{array}$ & $\begin{array}{c}(2) \\
\text { Socio- } \\
\text { demographic }\end{array}$ & $\begin{array}{c}(3) \\
\text { Economic }\end{array}$ & $\begin{array}{c}\text { (4) } \\
\text { Family/ } \\
\text { Gender }\end{array}$ & $\begin{array}{c}\text { (5) } \\
\text { Political } \\
\text { baseline }\end{array}$ & $\begin{array}{c}(6) \\
\text { Political } \\
\text { interactive }\end{array}$ & $\begin{array}{l}\text { (7) } \\
\text { Full }\end{array}$ \\
\hline Poljud distance & $\begin{array}{c}-0.037^{* * *} \\
(0.010)\end{array}$ & $\begin{array}{c}-0.032^{* * *} \\
(0.010)\end{array}$ & $\begin{array}{c}-0.051 * * * \\
(0.010)\end{array}$ & $\begin{array}{c}-0.037 * * * \\
(0.009)\end{array}$ & $\begin{array}{c}-0.039 * * * \\
(0.010)\end{array}$ & $\begin{array}{c}-0.039 * * * \\
(0.010)\end{array}$ & $\begin{array}{c}-0.036^{* * *} \\
(0.009)\end{array}$ \\
\hline Maksimir distance & $\begin{array}{c}0.046 * * * \\
(0.010)\end{array}$ & $\begin{array}{c}0.027 * * * \\
(0.008)\end{array}$ & $\begin{array}{c}0.050 * * * \\
(0.010)\end{array}$ & $\begin{array}{c}0.048 * * * \\
(0.010)\end{array}$ & $\begin{array}{c}0.040 * * * \\
(0.009)\end{array}$ & $\begin{array}{c}0.041 * * * \\
(0.009)\end{array}$ & $\begin{array}{c}0.044^{* * *} \\
(0.010)\end{array}$ \\
\hline Dalmatians & $\begin{array}{c}2.14^{* * *} \\
(0.544)\end{array}$ & $\begin{array}{c}2.55^{* * *} \\
(0.561)\end{array}$ & $\begin{array}{l}1.36^{* * *} \\
(0.527)\end{array}$ & $\begin{array}{l}1.91 * * * \\
(0.524)\end{array}$ & $\begin{array}{c}2.41 * * * \\
(0.563)\end{array}$ & $\begin{array}{c}2.31 * * * \\
(0.537)\end{array}$ & $\begin{array}{l}1.51^{* * *} \\
(0.490)\end{array}$ \\
\hline Football generation & $\begin{array}{c}73.55^{* * *} \\
(21.66)\end{array}$ & $\begin{array}{l}62.42^{*} \\
(32.04)\end{array}$ & $\begin{array}{c}69.62 * * * \\
(20.4)\end{array}$ & $\begin{array}{c}44.31 \\
(27.17)\end{array}$ & $\begin{array}{c}67.75 * * * \\
(22.26)\end{array}$ & $\begin{array}{c}69.26 * * * \\
(22.54)\end{array}$ & $\begin{array}{c}50.80 \\
(35.20)\end{array}$ \\
\hline Settlement size & & $\begin{array}{l}-0.745^{*} \\
(0.452)\end{array}$ & & & & & $\begin{array}{l}-0.321 \\
(0.460)\end{array}$ \\
\hline Croats & & $\begin{array}{c}13.20 * * * \\
(3.47)\end{array}$ & & & & & $\begin{array}{l}8.32 * * \\
(3.83)\end{array}$ \\
\hline Religious & & $\begin{array}{l}-23.25 \\
(19.4)\end{array}$ & & & & & $\begin{array}{l}-24.46 \\
(25.99)\end{array}$ \\
\hline Education & & $\begin{array}{l}1.96 * * \\
(0.840)\end{array}$ & & & & & $\begin{array}{c}0.607 \\
(0.948)\end{array}$ \\
\hline War & & $\begin{array}{l}-0.042 \\
(0.036)\end{array}$ & & & & & $\begin{array}{l}-0.047 \\
(0.032)\end{array}$ \\
\hline Income & & & $\begin{array}{l}0.154 \\
(2.70)\end{array}$ & & & & $\begin{array}{l}-4.22 \\
(2.91)\end{array}$ \\
\hline Unemployment & & & $\begin{array}{c}-36.64 * * * \\
(9.92)\end{array}$ & & & & $\begin{array}{c}-27.68^{* * *} \\
(8.87)\end{array}$ \\
\hline Dissimilarity index & & & & $\begin{array}{c}-0.388 \\
(8.15)\end{array}$ & & & $\begin{array}{c}1.88 \\
(8.58)\end{array}$ \\
\hline Female workforce & & & & $\begin{array}{c}17.04 \\
(13.04)\end{array}$ & & & $\begin{array}{c}12.46 \\
(13.23)\end{array}$ \\
\hline Married & & & & $\begin{array}{c}61.48 * * * \\
(18.78)\end{array}$ & & & $\begin{array}{c}31.83 \\
(21.53)\end{array}$ \\
\hline Referendum "No" & & & & $\begin{array}{c}50.74 * * * \\
(10.26)\end{array}$ & & & $\begin{array}{c}27.56 \\
(22.15)\end{array}$ \\
\hline HDZ vote & & & & & $\begin{array}{c}-11.49 * * * \\
(2.67)\end{array}$ & $\begin{array}{l}38.20^{*} \\
(19.57)\end{array}$ & $\begin{array}{c}63.60 * * * \\
(19.28)\end{array}$ \\
\hline Turnout & & & & & $\begin{array}{c}4.48 \\
(6.42)\end{array}$ & $\begin{array}{c}46.10 * * * \\
(17.49)\end{array}$ & $\begin{array}{c}52.11 * * * \\
(17.22)\end{array}$ \\
\hline HDZ vote $X$ Turnout & & & & & & $\begin{array}{c}-87.65^{* * *} \\
(33.67)\end{array}$ & $\begin{array}{c}-97.66 * * * \\
(31.16)\end{array}$ \\
\hline Invalid votes & & & & & $\begin{array}{c}-124.94 * * * \\
(42.34)\end{array}$ & $\begin{array}{c}-119.60 * * * \\
(43.18)\end{array}$ & $\begin{array}{l}-43.85 \\
(54.66)\end{array}$ \\
\hline Observations & 556 & 556 & 556 & 556 & 556 & 556 & 556 \\
\hline Log pseudolikelihood & -19.179 & -18.956 & -18.953 & -18.935 & -19.085 & -19.059 & -18.803 \\
\hline R-squared & 0.553 & 0.618 & 0.627 & 0.637 & 0.586 & 0.594 & 0.687 \\
\hline
\end{tabular}

Standard errors in parentheses; fractional logit used throughout; coefficients and standard errors multiplied by $10^{3}$ for ease of presentation. ${ }^{*} p<0.10,{ }^{* *} p<0.05,{ }^{* * *} p<0.01$ 
Figure 1. Geographic distribution of Our Hajduk membership

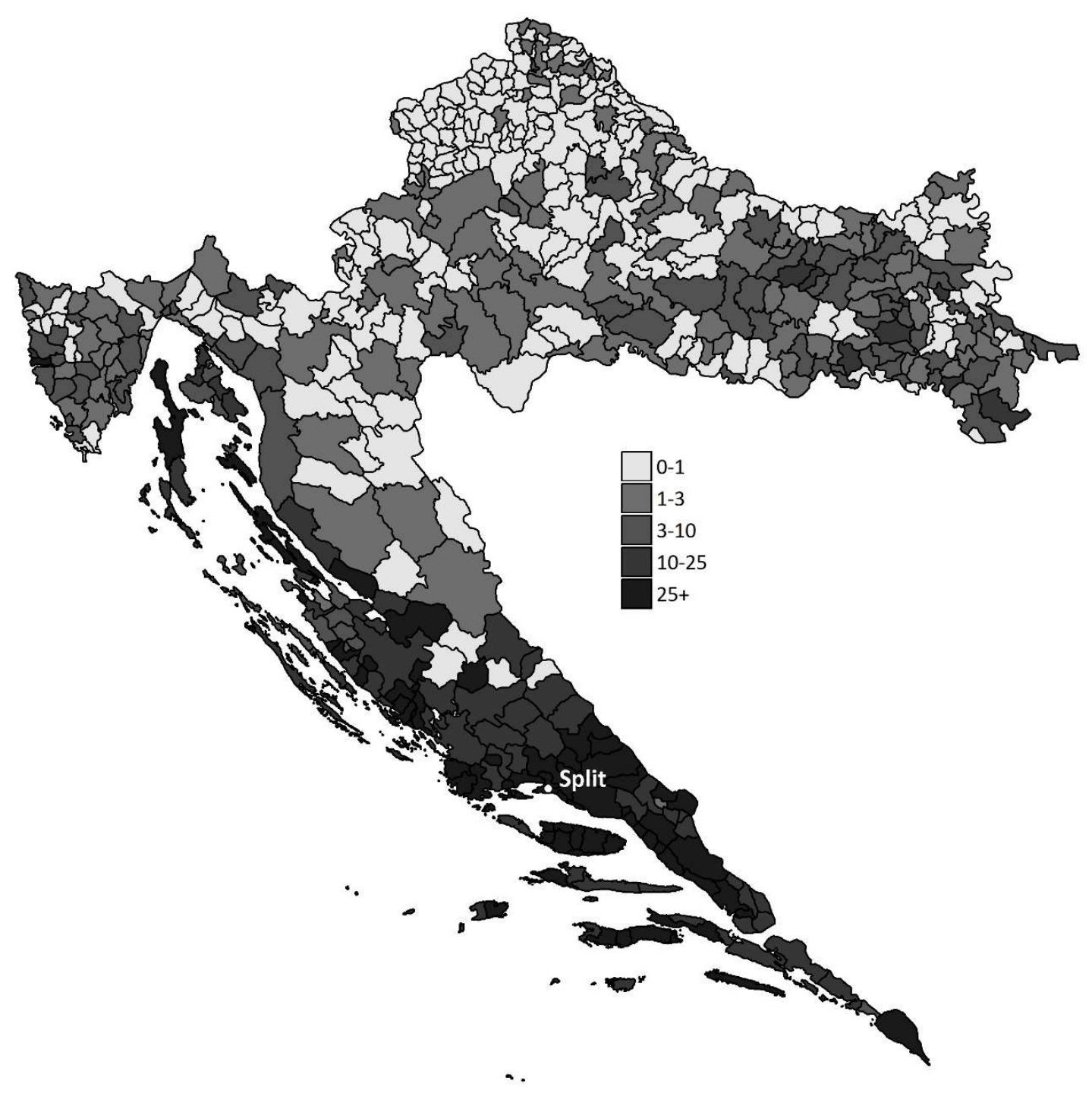


Figure 2. Conditional effect of electoral turnout on NH membership

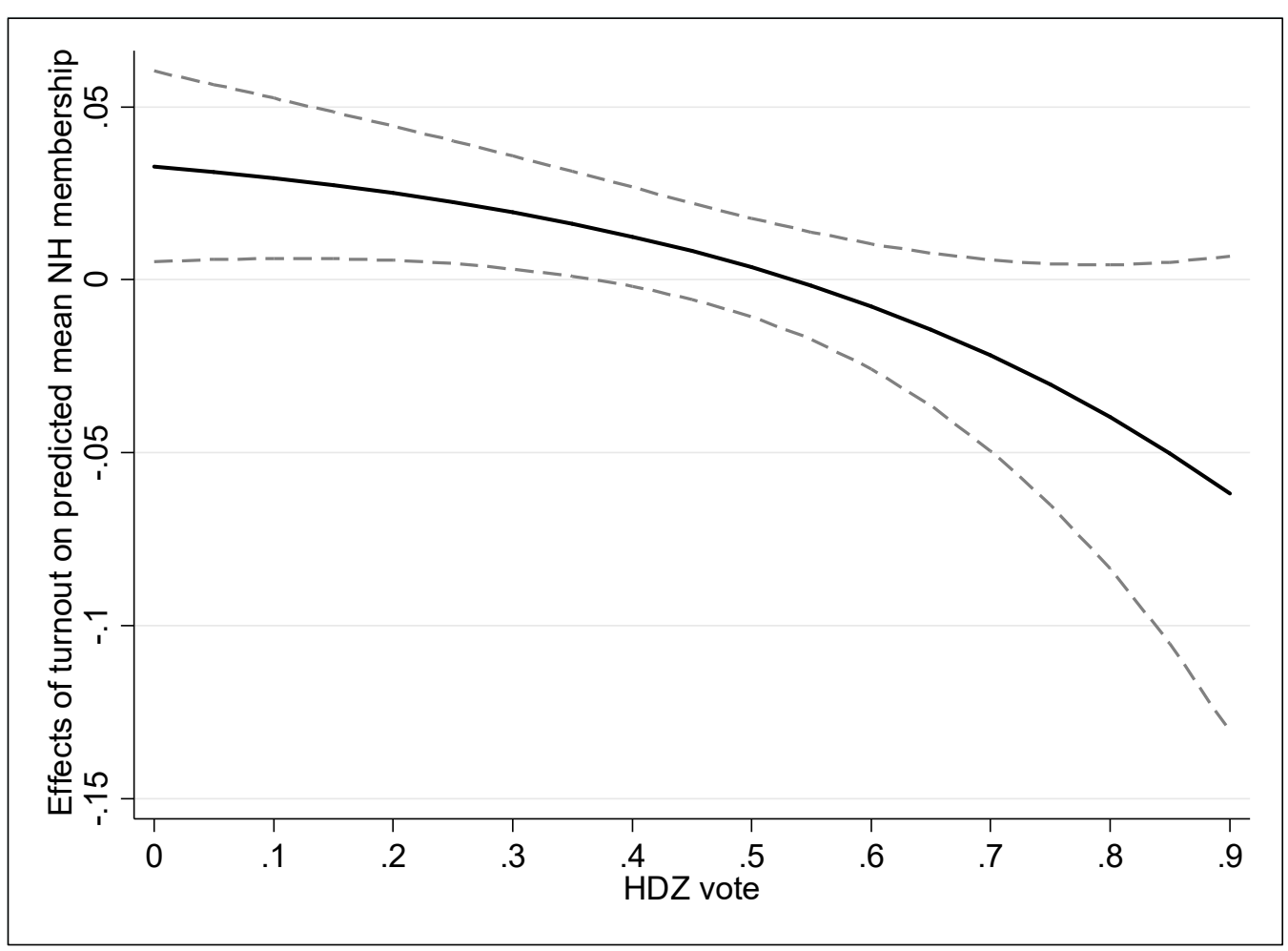

